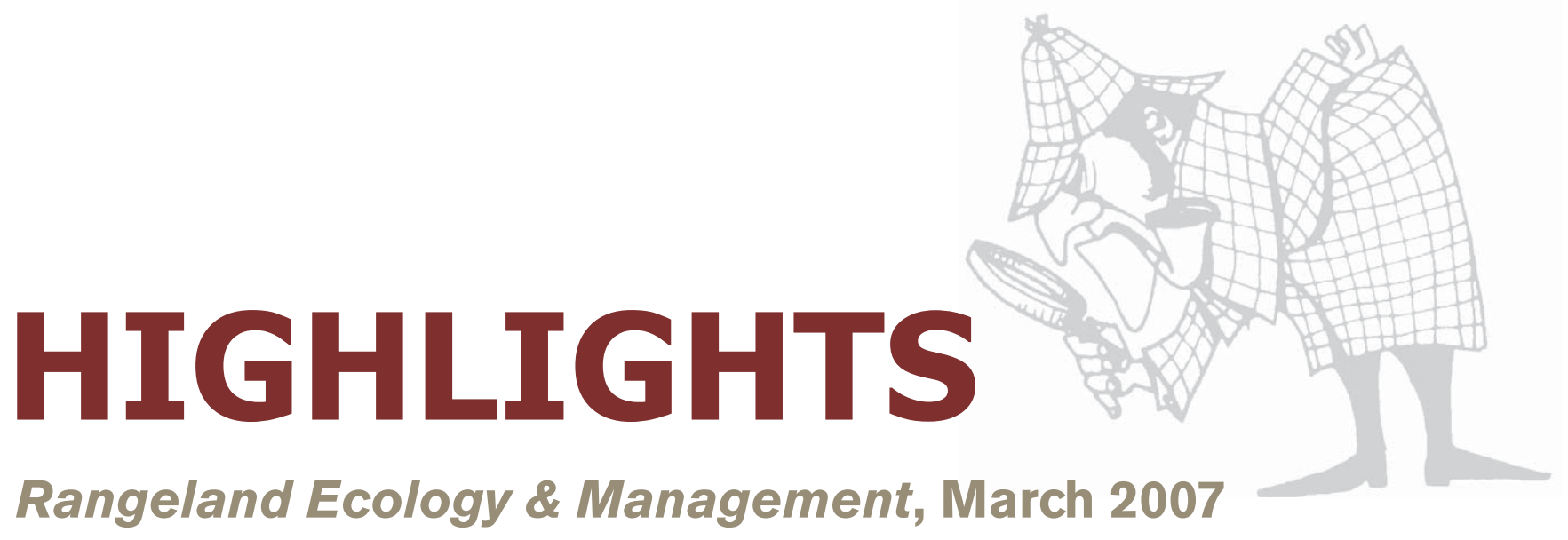

\section{Spatial Patterns of Pinyon-Juniper Woodland Expansion in Central Nevada}

Peter J. Weisberg, Emanuele Lingua, and Rekha B. Pillai

Conifer expansion in the Great Basin has received much attention, but little is known concerning how recent expansion rates have varied with spatial scale and across the landscape. We used historical air photos to quantify changes in treedominated area over the past three decades for a $25-\mathrm{km}^{2}$ area in central Nevada. Recent woodland expansion has been dominated by infilling of trees establishing in small openings, has progressed most rapidly at lower elevations, and is far more rapid on moister slope aspects and more well-developed soils. Management treatments involving removal of trees should be viewed in a long-term and site-specific context.

\section{Assessment of Expert Opinion: Seasonal Sheep Preference and Plant Response to Grazing}

Meg L. Pollock, Colin J. Legg, John P. Holland, and Chris M. Theobald

Expert opinion is often used in decision making and in rangeland models, but variation between experts is rarely taken into account. We asked nine experts about sheep preferences for Scottish rangeland plants at different times of the year and about plant responses to grazing at different times of the year. We found substantial agreement between experts on sheep preferences, but considerable uncertainty and disagreement about plant responses, especially on the impact of grazing in winter. This is important because seasonal grazing regimes for conservation are being developed-understanding their impact on vegetation is needed in order to meet management objectives.

\section{Forest Service Grazing Permittee Perceptions of the Endangered Species Act in Southeast- ern Arizona}

Julie Lorton Conley, Maria E. Fernandez-Gimenez, George B. Ruyle, and Mark Brunson
Much of the conflict over threatened and endangered (T\&E) species is centered on the presence and management of public land livestock grazing. This study reports the results of a survey of grazing permittees on one national forest about their attitudes regarding the Endangered Species Act and the management of T\&E species. Perceptions of negative impact and attitudes toward T\&E species policies were more related to attitudes toward federal regulation than the number of listed species on allotments or the potential for restrictions on those allotments. However, not all ranching operations perceive negative impacts from $\mathrm{T} \& \mathrm{E}$ species policies and many permittees would support efforts to recover $T \& E$ species.

\section{Using Weather Data to Explain Herbage Yield on Three Great Plains Plant Communities}

Alexander J. Smart, Barry H. Dunn, Patricia S. Johnson, Lan Xu, and Roger N. Gates

Understanding the drivers that account for plant production from different plant communities receiving similar climatic inputs can assist managers in making informed decisions about stocking rates and timing of grazing. We compared climatic drivers of herbage production for three plant communities of the Clayey ecological site in southwestern South Dakota. Herbage production was best predicted by models that included current year spring (April-June) precipitation, day of the last spring freeze, and previous year spring precipitation. Our study enables managers to make timely informed decisions regarding stocking rates and timing of grazing on this ecological site in western South Dakota.

\section{Texas Wintergrass and Buffalograss Response to Seasonal Fires and Clipping}

\section{R. James Ansley and Michael J. Castellano}

Effects of seasonal fires combined with grazing on rangeland grasses are poorly understood. We quantified effects of repeated winter fires, repeated summer fires, and clipping (to simulate grazing) on yields and percentage of live tissue of C3 Texas wintergrass (Nassella leucotricha) and C4 buffalo- 
grass (Buchlöe dactyloides). Results suggest: 1) both species were tolerant of summer fire, 2) fire with or without clipping stimulated buffalograss production, and 3) buffalograss was more tolerant than Texas wintergrass to combined effects of clipping plus fire. Different responses of $\mathrm{C} 3$ and $\mathrm{C} 4$ grass species to seasonal fire and grazing should be considered when determining management protocols.

\section{Long-Term Vegetation Productivity and Trends Under Two Stocking Levels on Chihuahuan Desert Rangeland}

\section{Godfrey Khumalo, Jerry Holechek, Milt Thomas, and Francisco Molinar}

In recent years many Chihuahuan Desert ranchers have become interested in light stocking as a tool to avoid risk of damaging their rangelands during drought and as a hedge against drastic destocking when cattle prices are often unfavorable. We compared vegetation cover, productivity, and composition over an 11-year period on 2 lightly- and 2 conservatively-stocked pastures. Light stocking had no benefit over conservative stocking in terms of increasing perennial grass productivity, but perennial grass cover was better maintained under light than conservative stocking. During the period of our study, climatic conditions rather than grazing treatment exerted the overriding influence on vegetation cover, composition, and productivity.

\section{Influence of Forest Mangement and Previous Herbivory on Cattle Diets}

\section{Kenric J. Walburger, Timothy DelCurto, and Martin Vavra}

We documented the effects of timber harvest and herbivory on nutritional quality and botanical composition of steer diets in grand fir (Abies grandis) and ponderosa pine (Pinus ponderosa) forests. Crude protein, in vitro organic matter digestibility, acid detergent fiber, and neutral detergent fiber were only affected by season of use. Within both sites, graminoids were the major constituent of the diet (65-91\%), forbs were intermediate $(8-31 \%)$, and shrubs were least $(0.2-3.5 \%)$. Timing of grazing had a greater influence on diet quality, but previous herbivory and/or timber harvest had a greater influence on diet composition.

\section{Effects of Wildlife on Cattle Diets in Laikipia Rangeland, Kenya}

\section{Wilfred O. Odadi, Truman P. Young, and}

\section{J. B. Okeyo-Owuor}

Little is known about how wildlife affect the diets of cattle, despite the fact that most livestock share their ecosystems with wildlife. Using a replicated set of large-scale exclosures in a savanna rangeland in Kenya, we quantified the diets of cattle both in the presence and in the absence of wildlife.
When in competition with wildlife, cattle shifted their diet, in particular eating fewer forbs (especially Commelina spp.) during the dry season. This research demonstrates that even moderate densities of wildlife can have significant effects on cattle diets, and potentially reduce livestock performance.

\section{Blackland Tallgrass Prairie Vegetation Dy- namics Following Cessation of Herbicide Application}

\section{Karen R. Hickman and Justin D. Derner}

Conservation of the endangered Blackland Tallgrass Prairie of Texas has focused on acquisition of remnants, the majority having a history of herbicide application.

We studied short-term responses of the plant community following cessation of long-term herbicide application. Substantial increases in plant cover from 1998 to 2000 were observed for annual forbs, but $\mathrm{C} 4$ perennial grass cover only marginally increased; thus dominance shifted from $\mathrm{C} 4 \mathrm{pe}-$ rennial grasses to annual forbs. Conservation efforts need to be cognizant that dramatic short-term effects on vegetation dynamics will occur following cessation of herbicide applications, and enhancement of perennial forbs might require seeding or transplanting species.

\section{Differences in Food Ingestion and Diges- tion Among Sheep Classified as High or Low Sagebrush Consumers}

M. J. Fraker-Marble, K. L. Launchbaugh, and J. W. Walker

We examined behavioral and digestive traits of sheep identified as high or low consumers of sagebrush. High sagebrush consumers ate the same amount of sagebrush as low consumers when they had unrestricted access to a basal ration of alfalfa pellets. When animals were restricted to $75 \%$ of their recommended energy requirement, sheep identified as high consumers ate more sagebrush than low consumers. In vivo digestibility of a diet containing 10\% fresh sagebrush and 90\% alfalfa/grass hay was higher for high sagebrush consumers than low consumers. Sheep that willingly consumed high amounts of sagebrush were able to digest diets containing sagebrush more efficiently than low sagebrush consumers.

\section{Learning Through Foraging Consequences: A Mechanism of Feeding Niche Separation in Sympatric Ruminants}

\section{Scott L. Kronberg and John W. Walker}

When two or more species of ruminants forage on the same area of rangeland, they seldom if ever eat the same plants or parts of the same plants. If desired, we could manage their foraging more effectively with a better understanding of the mechanisms underlying their plant selection. In this paper, it is argued that the learning-through-foraging-consequences 
model of diet selection offers a unique explanation for the diets selected by sympatric ruminant species. Fortunately, this model implies that management interventions such as supplementation of ruminants can be used to alter their diet selection and thus provide a valuable management tool.

\section{The Influence of Gap Size on Sagebrush Cover Estimates With the Use of Line Inter- cept Technique}

\section{Chad S. Boyd, Jon D. Bates, and Rick F. Miller}

Sagebrush cover is often estimated using the line intercept method; however, a lack of standardized protocols can lead to conflicting estimates. We measured sagebrush canopy intercept using 5-, 10-, and 15-cm-gap sizes and compared live and dead sagebrush canopy cover estimates resulting from each gap size. Total cover estimates were not related to gap size, live canopy cover estimates increased with increasing gap size, and cover of dead material decreased with increasing gap size. Use of a standardized gap size will enhance comparabil- ity of canopy cover estimates among studies and will decrease between-year sampling error for repeat monitoring.

\section{A Passive Application Watering System for Rangeland Plots}

Patrick E. Reece, Ann E. Koehler, W. Douglas Whisenhunt, Jerry D. Volesky, and Walter H. Schacht

Interactions between precipitation regimes and optimum air temperatures for growth of different species often have measurable effects on peak standing herbage and species composition. Therefore, we developed the portable Passive Application Watering System (PAWS) which is suitable for applying water over a wide range of slope, soil texture, and residual herbage conditions with little or no runoff. Application rates were $5 \mathrm{~mm} \cdot \mathrm{hr}^{-1}$ and $40 \mathrm{~mm} \cdot \mathrm{hr}^{-1}$, which correspond to the permeability of clay loam and silt loam, respectively. We have successfully used the PAWS in 3 research projects on range sites with sandy and loamy soil texture classes. 